\title{
SÚ SÚČASNÉ CHATBOTY VYUŽÍVANÉ POŠTOVÝMI OPERÁTORMI POSKYTUJÚCIMI UNIVERZÁLNU SLUŽBU V RÁMCI EÚ POSTAČUJÚCE?
}

\author{
Dominika Koncová ${ }^{1}$, Iveta Kremeňová ${ }^{2}$
}

\begin{abstract}
The article presents the testing of search engines and chatbots of postal operators of the universal postal service within the European Union for the ability to search for key phrases consisting of text. Based on the analysis, it was found that search engines as well as chatbots were in many cases insufficiently designed and would need to be upgraded.
\end{abstract}

Keywords: search engine, chatbots, AI

\section{Úvod}

V súčasnom 21. storočí už bežný užívatel' internetu nepožaduje od webstránky len poskytnutie informácí́. Ale tým, že doba pokročila a mnohé informácie boli prenesené z tlačenej podoby do digitálnej, je nutné, aby bolo jednoduché takéto informácie vyhl'adávat' rýchlo a efektívne z hl'adiska času, na základe zadávania vhodných kl'účových slov. Preto je vhodné, ked' je možné, prostredníctvom IKT technológií, zabezpečit' rýchlu a správnu odozvu na definovaný dopyt vo vyhl'adávacom poli vyhl'adávacieho nástroja jednotlivých webstránok, prípadne vyhl'adávačov konkrétnych prehliadačov. V súčasnosti sújednotlivé vyhl'adávače ako prehliadačov, tak aj webstránok inovované na novšie verzie, ktoré umožňujú lepšiu odozvu v rámci online interakcie. [1]

Nástroje na vyhl'adávanie sa používajú dlhé desat'ročia, prakticky takmer odkedy bol internet zverejnený verejnosti. V súčasnosti sa ich vývoj však preniesol do postupného zlepšovania technológie takýchto vyhl'adávačov. S významnými zlepšeniami v tejto oblasti prišiel Google. [2] [3] Tým, že vyhl'adávanie už nemusí byt' striktne ohraničené jedným dvoma kl’účovými slovami, ale využíva sa skôr vyhl'adávanie pomocou fráz, ktoré vyhl'adávač rozoznáva v rámci kontextu, je pre vyhl'adávač jednoduchšie vyhl'adat' požadované informácie. Nejedná sa pri tom len o frázy, ale aj o vyhl’adávanie základov slov. Preto je obvykle odozva $\mathrm{z}$ takéhoto vyhl'adávania aj $\mathrm{v}$ desiatkach „odpovedí“ resp. vygenerovaných dokumentov namiesto niekol'kých viac relevantnejších. Niektoré spoločnosti sa však rozhodli toto vyhl'adávanie ešte viac posunút' a zlepšit' a to tým, že namiesto v súčasnosti už bežného vyhl'adávača, využívajú chatboty.

Inteligentný agent alebo inak aj chatbot (konverzačný agent, robot) je zariadenie, ktoré je schopné porozumiet' svojmu prostrediu a podniknút' kroky maximalizujúce šancu na dosiahnutie nejakého vopred určeného ciel'a a sú schopné počas komunikácie porozumiet' odpovedi na l'udský jazyk prostredníctvom používatel'ského rozhrania. [4] [5] Mnohé z nich sú naprogramované na to, aby fungovali na princípe vyhl'adávača, iné Vám generujú len

\footnotetext{
1 Ing. Dominika Koncová, Žilinská univerzita v Žiline, Fakulta prevádzky a ekonomiky dopravy a spojov, Katedra spojov, Univerzitná 8215/1,01026 Žilina, Slovensko, e-mail: dominika.koncova@stud.uniza.sk

2 doc. Ing. Iveta Kremeňová, PhD., Žilinská univerzita v Žiline, Fakulta prevádzky a ekonomiky dopravy a spojov, Katedra spojov, Univerzitná 8215/1, 01026 Žilina, Slovensko, e-mail: iveta.kremenova@fpedas.uniza.sk
} 
odpovede na vopred prednastavené otázky (napr. Poštová asistentka od Slovenskej pošty), d’alšie majú predprogramovanú len určitú sadu úkonov a teda takýto chatbot nie je schopný odpovedat' alebo generovat' na otázky napr. bežného hl'adania. Iné chatboty sú naprogramované na báze umelej inteligencie (AI) a na základe predošlého vyhl'adávania užívatel'mi webových stránok sú schopné samovzdelávania, prípadne je, či už v chatbotoch alebo vo vyhl'adávačoch naprogramovaná predikcia. Všetko to najmä závisí od požiadaviek ako zákazníkov jednotlivých spoločností, tak od podniku, ktorému daná webová stránka patrí.

\section{Ciel' a metodológia}

Ciel'om článku je poukázat' na zastaranost' a niektoré nedostatky vyhl'adávačov a chatbotov u poštových operátorov poskytujúcich univerzálnu poštovú službu v rámci Európskej únie. Kvalitatívnou metódou bol na základe stanovených fráz resp. klúčových slov v šiestich kombináciách podrobený vyhladávač a pri chatbotoch bola vyvinutá snaha o získanie navigácie, prípadne vhodného odkazu na relevantné prepojenie o spoločnosti. Následne boli získané údaje vyhodnotené a porovnané medzi sebou.

\section{Výsledky}

Ked’že Slovensko patrí do krajín EÚ, bolo vhodné analyzovat' a následne porovnat' poskytovatel'ov UNS v rámci tohto integračného zoskupenia. Pri analyzovaní použitia chatbota a vyhl'adávača na webových stránkach jednotlivých operátorov sme postupovali rovnako. Na stránke operátora, bol zvolený jazyk angličtina (ak to webstránka umožňovala) pre jednotnost' vyhl'adávania na stránkach operátorov a následne bolo preskúmané, či má stránka vyhl'adávač. Ďalej bolo overené, či je na stránke chatbot alebo niečo, čo sa štruktúrou alebo vlastnost’ami chatbotovi podobá, ako je možné vidiet' v tabul'ke č.1. Následne bol vyhl'adávač aj chatbot podrobený skúške.

Tabul'ka 1 Operátori poskytujúci univerzálnu poštovú službu v rámci Európskej únie a ich využívanie alebo nevyužívanie nástrojov vyhl’adávania a chatbota na ich webových stránkach

\begin{tabular}{|c|c|c|c|c|}
\hline P.Č. & Krajina & Pošta & Chatbot & Vyhl'adávanie \\
\hline 1 & Belgicko & Bpost & $\bar{\square}$ & $\checkmark$ \\
\hline 2 & Bulharsko & Bulgarian posts & $\checkmark$ & $\checkmark$ \\
\hline 3 & Chorvátsko & Hrvatska pošta & 区 & $\checkmark$ \\
\hline 4 & Cyprus & Cyprus post & $\bar{\square}$ & $\checkmark$ \\
\hline 5 & Cesko & Ceská pošta & $\overline{\mathrm{x}}$ & $\checkmark$ \\
\hline 6 & Dánsko & Post Danmark & 凶 & $\checkmark$ \\
\hline 7 & Estónsko & Eesti post & 区 & $\checkmark$ \\
\hline 8 & Fínsko & Posti & $\bar{\square}$ & $\checkmark$ \\
\hline 9 & Francúzsko & La Poste & $\bar{\square}$ & $\checkmark$ \\
\hline 10 & Grécko & ELTA Hellenic post & $\bar{\square}$ & $\checkmark$ \\
\hline 11 & Holandsko & Post NL & 区 & $\checkmark$ \\
\hline 12 & Írsko & An Post & $\checkmark$ & 区 \\
\hline 13 & Litva & Lietuvos Paštas & 区 & $\checkmark$ \\
\hline 14 & Lotyšsko & Latvijas pasts & $\bar{\square}$ & $\checkmark$ \\
\hline 15 & Luxembursko & Post Luxembourg & 凶 & $\checkmark$ \\
\hline 16 & Mad'arsko & Magyar Posta & $\bar{\square}$ & $\checkmark$ \\
\hline 17 & Malta & Malta Post & 区 & $\checkmark$ \\
\hline 18 & Nemecko & Deutsche Post & 区 & $\checkmark$ \\
\hline 19 & Pol'sko & Poczta Polska & $\bar{\square}$ & $\checkmark$ \\
\hline 20 & Portugalsko & Correios de Portugal & $\bar{\nabla}$ & $\checkmark$ \\
\hline 21 & Rakúsko & Austrian Post & 凶 & $\checkmark$ \\
\hline 22 & Rumunsko & Posta Romana & $\bar{\square}$ & $\checkmark$ \\
\hline 23 & Slovensko & Slovenská pošta & $\checkmark$ & $\checkmark$ \\
\hline 24 & Slovinsko & Pošta Slovenije & $\bar{\square}$ & $\checkmark$ \\
\hline 25 & Španielsko & Spain post - Grupo Correos & 区 & $\sqrt{ }$ \\
\hline 26 & Švédsko & PostNord & $\checkmark$ & $\checkmark$ \\
\hline 27 & Taliansko & Poste Italiane & $\bar{\square}$ & $\checkmark$ \\
\hline
\end{tabular}

Zdroj: autori po spracovaní informácií z [6-32]

Vo vyhl'adávači boli zvolené jednotlivo kl'účové slová: „about us“, ,about company“, „about $X Y$ “ (kde XY predstavuje názov poštového operátora v danej krajine), ak ani jedna 
z týchto troch kombinácií nepriniesla výsledok, boli testované kombinácie ,information about $X Y “$, „XY information“ a ,information“. Na záver vyhl'adávania bolo na úvodnej stránke overené, či sa tam takéto frázy nachádzajú. Tieto kl'účové slová boli zvolené preto, lebo je pravidlom, aby mala firma na svojej webovej stránke aspoň nejaké základné informácie o sebe a svojej činnosti. Získané údaje sú uvedené v tabul'ke č. 2, kde v stĺpci jazyk je zobrazená skratka štátu, používajúceho daný jazyk. Vo väčšine prípadov bolo možné použit' angličtinu (GB), ale v niektorých prípadoch: gréčtina (EL), nemčina (DE), pol'ština (PL), portugalčina (PT) a francúzština (FR), ju nebolo možné použit'.

Tabul'ka 2 Operátori poskytujúci univerzálnu poštovú službu v rámci Európskej únie a schopnosti vyhl'adávača vyhl'adat' stanovené frázy

\begin{tabular}{|c|c|c|c|c|c|c|c|c|c|}
\hline \multirow{2}{*}{$\begin{array}{l}\text { P. } \\
\check{C} \text {. }\end{array}$} & \multirow[b]{2}{*}{ Krajina } & \multirow[b]{2}{*}{ Pošta } & \multirow[b]{2}{*}{ Jazyk } & \multicolumn{6}{|c|}{ Vyhl’adávanie kl’účových slov cez vyhl’adávač } \\
\hline & & & & $\begin{array}{c}\text { "About } \\
\text { us" }\end{array}$ & $\begin{array}{c}\text { „About } \\
\text { company“ }\end{array}$ & $\begin{array}{l}\text { About } \\
\text { XY“ }\end{array}$ & $\begin{array}{c}\text { „Information } \\
\text { about XY“ }\end{array}$ & $\begin{array}{c}\text { „XY } \\
\text { information“ }\end{array}$ & „information“ \\
\hline 1 & Belgicko & Bpost & GB & - & - & - & - & - & - \\
\hline 2 & Bulharsko & Bulgarian posts & $\mathrm{GB}$ & - & I & I & I & I & I \\
\hline 3 & Chorvátsko & Hrvatska pošta & GB & - & - & - & - & - & - \\
\hline 4 & Cyprus & Cyprus post & EL & - & - & - & I & I & I \\
\hline 5 & Česko & Česká pošta & GB & $\mathrm{I}$ & I & I & $\mathrm{I}$ & I & $\mathrm{I}$ \\
\hline 6 & Dánsko & Post Danmark & GB & I & I & I & I & I & I \\
\hline 7 & Estónsko & Eesti post & GB & $\mathrm{I}$ & $\mathrm{I}$ & $\mathrm{I}$ & $\mathrm{I}$ & $\mathrm{I}$ & $\mathrm{I}$ \\
\hline 8 & Fínsko & Posti & GB & - & - & - & - & - & - \\
\hline 9 & Francúzsko & La Poste & FR & - & - & - & - & - & - \\
\hline 10 & Grécko & $\begin{array}{l}\text { ELTA Hellenic } \\
\text { post }\end{array}$ & GB & - & I & I & I & I & - \\
\hline 11 & Holandsko & Post NL & GB & I & I & I & I & I & I \\
\hline 12 & Írsko & An Post & - & - & - & - & - & - & - \\
\hline 13 & Litva & Lietuvos Paštas & GB & - & - & - & - & - & - \\
\hline 14 & Lotyšsko & Latvijas pasts & GB & - & - & - & - & - & - \\
\hline 15 & Luxembursko & $\begin{array}{l}\text { Post } \\
\text { Luxembourg }\end{array}$ & GB & - & - & - & - & - & - \\
\hline 16 & Mad'arsko & Magyar Posta & GB & I & I & I & I & I & - \\
\hline 17 & Malta & Malta Post & GB & $\mathrm{I}$ & - & - & - & - & $\mathrm{I}$ \\
\hline 18 & Nemecko & Deutsche Post & $\mathrm{DE}$ & - & - & - & - & - & - \\
\hline 19 & Pol'sko & Poczta Polska & $\mathrm{PL}$ & - & $\mathrm{I}$ & - & - & - & - \\
\hline 20 & Portugalsko & $\begin{array}{l}\text { Correios de } \\
\text { Portugal }\end{array}$ & PT & - & - & - & - & - & - \\
\hline 21 & Rakúsko & Austrian Post & GB & - & - & - & - & - & - \\
\hline 22 & Rumunsko & Posta Romana & GB & $\mathrm{I}$ & $\mathrm{I}$ & $\mathrm{I}$ & $\mathrm{I}$ & - & \\
\hline 23 & Slovensko & Slovenská pošta & GB & - & - & - & - & - & $\mathrm{I}$ \\
\hline 24 & Slovinsko & Pošta Slovenije & GB & - & I & I & I & - & - \\
\hline 25 & Španielsko & $\begin{array}{l}\text { Spain post - } \\
\text { Grupo Correos }\end{array}$ & GB & - & - & I & I & I & - \\
\hline 26 & Švédsko & PostNord & GB & $\mathrm{I}$ & I & I & I & I & - \\
\hline 27 & Taliansko & Poste Italiane & GB & - & - & - & - & - & - \\
\hline
\end{tabular}

Zdroj: autori po spracovaní informácií z [6-32]

Výsledky takejto analýzy boli nasledovné. U takmer 52\% uvedených operátorov, bolo možné nájst' informácie o spoločnosti niektorou z prvej 3-kombinácie fráz. Vo zvyšných 48\% bolo nutné použit' druhú 3-kombináciu klúčových slov. Nájdenie požadovaných informácií pomocou kl'účových slov „,about us“ a ,information“ bolo úspešné v oboch prípadoch len na $30 \%$. Naopak najúspešnejšia kombinácia slov na vyhl'adávanie takýchto informácií je pomocou pomerne dlhej frázy ,information about XY“, ktorá dosiahla až 44\% úspešnost'. Ďalšími v poradí boli ,about company“ a „about XY“, ktoré dosiahli $41 \%$ úspešnost' hl'adanie. Len 2 operátori potrebovali zadat' samostatne ,information“. Jednalo sa o Slovensko a Maltu, avšak Malta poskytla informácie o spoločnosti už v prvom prípade.

U 12 podnikov z 27 bolo nájdenie informácií pomocou uvedených klúčových slov neúspešné. V nich bola následne hladaná informácia o spoločnosti ako odkaz, či už v hornej alebo dolnej časti webstránky. V tomto prípade $75 \%$ stránok malo takýto odkaz.

Írsko vyhl'adávač nepoužíva, namiesto neho používa chatbot. Niektoré webstránky taktiež vyhl'adávajú len v rodnom jazyku (nemčina, portugalčina, pol’ština, francúzština), kde možné rozdiely vo vyhl'adávaní mohli byt' spôsobené jazykovou gramotnost'ou autorov. 
V týchto prípadoch bol použitý prekladač z jazyku angličtina do uvedených jazykov, avšak úspešnost' bola zjavne nižšia.

Následne boli preverené aj chatboty, prípadne nástroje webstránky, ktoré sa svojou koncepciou chatbotom podobali (Hjälp od PostNord vo Švédsku). Z poštových operátorov poskytujúcich UNS v rámci EÚ, mali len štyri krajiny chatbota alebo tzv. pomoc. Jednalo sa o Bulharsko, Írsko, Slovensko a Švédsko. Bpost disponuje niečím, čo sa povahou podobá chatbotu, ale je to prakticky len presmerovanie na kontaktný formulár. Chatboty operátorov poskytujúcich univerzálnu službu v členských štátoch EÚ sú uvedené v tabul'ke č. 3.

Tabul'ka 3 Operátori poskytujúci univerzálnu poštovú službu v rámci Európskej únie a schopnosti chatbota vyhl'adat' stanovené frázy

\begin{tabular}{|c|c|c|c|c|c|c|c|c|c|c|}
\hline \multirow[b]{2}{*}{$\mathbf{P C}$} & \multirow[b]{2}{*}{ Krajina } & \multirow[b]{2}{*}{ Pošta } & \multirow[b]{2}{*}{ Jazyk } & \multicolumn{7}{|c|}{ Vyhl'adávanie kl'účových slov cez vyhl'adávač } \\
\hline & & & & $\begin{array}{l}\text { "About } \\
\text { us" }\end{array}$ & \begin{tabular}{|c|} 
„About \\
company“
\end{tabular} & $\begin{array}{l}\text { "About } \\
\text { XY“" }\end{array}$ & $\begin{array}{c}\text { "Information } \\
\text { about XY“ }\end{array}$ & \begin{tabular}{c|} 
„XY \\
information“"
\end{tabular} & ,information““ & iné \\
\hline 2 & Bulharsko & $\begin{array}{l}\text { Bulgarian } \\
\text { posts }\end{array}$ & BG & - & - & - & - & - & - & $\mathrm{x}$ \\
\hline 12 & Írsko & An Post & GB & - & - & - & - & - & - & About An Post \\
\hline 15 & Luxembursko & $\begin{array}{l}\text { Post } \\
\text { Luxembourg }\end{array}$ & $\begin{array}{l}\text { GB, } \\
\text { DE, } \\
\text { FR }\end{array}$ & - & - & - & - & - & - & POST Group \\
\hline 23 & Slovensko & $\begin{array}{l}\text { Slovenská } \\
\text { pošta }\end{array}$ & SK & - & - & - & - & - & - & Information \\
\hline 26 & Švédsko & PostNord & SV & - & - & - & - & - & - & About us \\
\hline
\end{tabular}

Zdroj: autori po spracovaní informácií z [6-32]

Chatbot Bulharskej pošty sa nazýva Български Пощи (Bulharské príspevky). Z uvedených kl'účových slov nebol schopný vygenerovat' ani jednu správnu odpoved'. Komunikácia je možná len po bulharsky. Z dôvodu jazykovej bariéry odkaz na získanie týchto informácií hl'adaný nebol. Írska An Post využíva svojho chatbota - OscarBot namiesto vyhl'adávača avšak nie je schopný poskytnút' informácie týkajúce sa uvedených kl'účových slov. Je však schopný sledovat' zásielku, poskytnút' informácie o správnom balení a registrovaní zásielky. Komunikácia s OscarBotom bola možná len po anglicky. Pre získanie týchto informácií je nutné nájst' a otvorit’ odkaz.

Poštová asistentka od Slovenskej pošty je značne obmedzená v koncepcií schopnosti odpovedat' na otázky. Prakticky bez rozdielu na to, či si zvolíte ako jazyk angličtinu alebo slovenčinu, tak tento chatbot komunikuje len po slovensky. Z hl'adiska získania požadovaných informácií je tiež nevhodne navrhnutá, lebo zákazník sa nemôže spýtat' na čokol'vek, čo nenašiel v rámci hl'adania cez vyhl'adávač, ale môže si len vyberat' z predefinovaných možností, ktoré v konečnom dôsledku požadujú získanie informácií do štatistík. Požadované informácie je možné získat' otvorením odkazu Informácie.

Luxemburská pošta má okrem vyhl’adávača aj pomocníka označeného „?““. Tento však funguje len ako kontaktný formulár alebo odporúča len 2 možnosti, kde hl'adat' odpovede. Preto tohto pomocníka nie je ani vhodné definovat' ako chatbota. Komunikácia tohto pomocníka je však možná $v$ troch jazykoch, angličtine, nemčine a francúzštine avšak pomocník nedisponuje vyhl'adávacím oknom. Hjälp od švédskej PostNord komunikuje len v švédčine. Po preklade z angličtiny do švédčiny pomocou prekladača, vyhl'adávacie okno tohto pomocníka nebolo schopné vygenerovat' relevantné odkazy k požadovaným klúčovým slovám. Z uvedených chatbotov len 2 uviedli, možnost' samovzdelávania sa, resp. d'alšieho učenia sa. Nebolo síce predefinované, či tieto chatboty fungovali na vyššej úrovni AI alebo len ako program, ktorý musia IT špecialisti vylepšit', avšak bola tu aspoň zjavná snaha o zlepšenie.

\section{Záver}

Na základe analýzy bolo zistené, že poštoví operátori, poskytujúci univerzálnu službu v krajinách EÚ, sa skôr orientujú pri tvorbe svojich chatbotov na sledovanie zásielky, tvorbu prieskumov, uvádzanie poštových alebo prepravných podmienok, resp. na prácu so zásielkou. 
Z hl'adiska vyhl'adávačov, viac než $80 \%$ bolo koncipovaných tak, aby boli schopné vyhl'adávat' aj text a aby boli schopné podat' relevantné výsledky k požiadavkám hl'adania. Zvyšné vyhl'adávače však boli pripravené podobne ako chatboty, teda na sledovanie zásielok a informáciám spojeným $\mathrm{s}$ jej podaním alebo prevzatím. V princípe by teda bolo výhodné, aby poštoví operátori, ktorí sa rozhodnú využívat' chatbota a zároveň využívat' aj vyhl'adávacie pole, umožnili aspoň jednej z týchto technológií generovanie výsledkov aj pre informácie, týkajúce sa aj iných informácií ako len zásielok alebo prvotných požiadaviek k nim. Taktiež by to mohlo poslúžit' pri realizácií výskumov alebo projektov s nutnost'ou dohl'adávat' špecifické informácie excerpovaním údajov aj z textových zdrojov zameraných na niečo iné, ako vyššie uvedené kategórie.

\section{Literatúra}

[1] Kremenova, I., Gajdos, M. 2019. Decentralized networks: The future internet. Mobile Networks and Applications, 24(6), 2016-2023.

[2] Androutsopoulou, A., Karacapilidis, N., Loukis, E., Charalabidis, Y. 2019. Transforming the communication between citizens and government through AI-guided chatbots. Government Information Quarterly, 36(2), 358-367.

[3] Węcel, K., Zhdanova, A. V. 2005. Information Delivery for the End User of the Semantic Web. In Proceedings of the ESWC 2005 Workshop on End User Aspects of the Semantic Web (Vol. 29, pp. 1613-0073).

[4] Brewka, G. 2009. Artificial intelligence - a modern approach by Stuart Russell and Peter Norvig, Prentice Hall. Series in Artificial Intelligence, Englewood Cliffs, NJ. The Knowledge Engineering Review, 11(1), 78-79.

[5] Brin, S., \& Page, L. 1998. The anatomy of a large-scale hypertextual web search engine. Computer networks and ISDN systems, 30(1-7), 107-117.

[6] Webová stránka poskytovatel’a UNS v Belgicku bpost. [Cit. 12.4.2021]. Dostupné on-line na: < https://www.bpost.be/en $>$.

[7] Webová stránka poskytovatel'a UNS v Bulharsku Bulgarian post. [Cit. 12.4.2021]. Dostupné on-line na: < https://www.bgpost.bg/en >.

[8] Webová stránka poskytovatel'a UNS v Chorvátsku Hrvatska pošta. [Cit. 12.4.2021]. Dostupné on-line na: < https://www.posta.hr/en $>$.

[9] Webová stránka poskytovatel'a UNS v Cyprus Cyprus post. [Cit. 12.4.2021]. Dostupné on-line na: < https://www.cypruspost.post/en/home $>$.

[10] Webová stránka poskytovatel’a UNS v Česku Česká pošta. [Cit. 12.4.2021]. Dostupné online na: < https://www.ceskaposta.cz/index $>$.

[11] Webová stránka poskytovatel’a UNS v Dánsku Post Nord - Post Danmark. [Cit. 12.4.2021]. Dostupné on-line na: < https://www.postnord.dk/en $>$.

[12] Webová stránka poskytovatel'a UNS v Estónsku Omniva - Eesti post. [Cit. 12.4.2021]. Dostupné on-line na: $<$ https://www.omniva.ee/eng $>$.

[13] Webová stránka poskytovatel'a UNS v Fínsku Posti. [Cit. 12.4.2021]. Dostupné on-line na: < https://www.posti.fi/en $>$.

[14] Webová stránka poskytovatel’a UNS v Francúzsku La Poste. [Cit. 12.4.2021]. Dostupné on-line na: < https://www.laposte.fr/ >.

[15] Webová stránka poskytovatel’a UNS v Grécku ELTA Hellenic post. [Cit. 12.4.2021]. Dostupné on-line na: $<$ https://www.elta.gr/en-us/home.aspx $>$.

[16] Webová stránka poskytovatel'a UNS v Holandsku Post NL. [Cit. 12.4.2021]. Dostupné on-line na: $<$ https://www.postnl.nl/en/ $>$.

[17] Webová stránka poskytovatel'a UNS v Írsku An Post. [Cit. 12.4.2021]. Dostupné online na: < https://www.anpost.com/ >. 
[18] Webová stránka poskytovatel'a UNS v Litve Lietuvos Paštas. [Cit. 12.4.2021]. Dostupné on-line na: < https://www.post.lt/ >.

[19] Webová stránka poskytovatel'a UNS v Lotyšsku Latvijas pasts. [Cit. 12.4.2021]. Dostupné on-line na: < https://pasts.lv/en/ >.

[20] Webová stránka poskytovatel'a UNS v Luxembursku Post Luxembourg. [Cit. 12.4.2021]. Dostupné on-line na: < https://www.post.lu/en/ >.

[21] Webová stránka poskytovatel'a UNS v Mad'arsku Magyar Posta. [Cit. 12.4.2021]. Dostupné on-line na: < https://www.posta.hu/international_main $>$.

[22] Webová stránka poskytovatel’a UNS na Malte Malta Post. [Cit. 12.4.2021]. Dostupné online na : < https://www.maltapost.com/ >.

[23] Webová stránka poskytovatel'a UNS v Nemecku Deutsche Post. [Cit. 12.4.2021]. Dostupné on-line na: < https://www.deutschepost.de/de.html $>$.

[24] Webová stránka poskytovatel'a UNS v Pol'sku Poczta Polska. [Cit. 12.4.2021]. Dostupné on-line na: < https://www.poczta-polska.pl/ >.

[25] Webová stránka poskytovatel'a UNS v Portugalsku Correios de Portugal. [Cit. 12.4.2021]. Dostupné on-line na: < https://www.ctt.pt/grupo-ctt/ $>$.

[26] Webová stránka poskytovatel'a UNS v Rakúsku Austrian Post. [Cit. 12.4.2021]. Dostupné on-line na: $<$ https://www.post.at/en $>$.

[27] Webová stránka poskytovatel'a UNS v Rumunsku Posta Romana. [Cit. 12.4.2021]. Dostupné on-line na: < https://www.posta-romana.ro/en/ > .

[28] Webová stránka poskytovatel'a UNS na Slovensku Slovenská pošta. [Cit. 12.4.2021]. Dostupné on-line na: < https://www.posta.sk/ >.

[29] Webová stránka poskytovatel'a UNS v Slovinsku Pošta Slovenije. [Cit. 12.4.2021]. Dostupné on-line na: $<$ https://en.posta.si/home $>$.

[30] Webová stránka poskytovatel’a UNS v Španielsku Spain post - Grupo Correos. [Cit. 12.4.2021]. Dostupné on-line na: < https://www.postnord.se/en $>$.

[31] Webová stránka poskytovatel'a UNS vo Švédsku PostNord. [Cit. 12.4.2021]. Dostupné on-line na: < https://www.posteitaliane.it/en/index.html $>$.

[32] Webová stránka poskytovatel'a UNS v Taliansku Poste Italiane. [Cit. 12.4.2021]. Dostupné on-line na: $<$ https://www.posteitaliane.it/en/index.html $>$.

\section{Grantová podpora}

Článok bol publikovaný s podporou projektu 1/0518/19. Ďalej bol článok podporený Žilinskou univerzitou v rozsahu Inštitucionálneho výskumu 1/KS/2020 a Projektom CIS od Ministerstva školstva SR. 